least. Although it makes some pretentions to original research it reveals a very slight acquaintance with unprinted material. Mr. Williamson has made some use of unpublished documents in English archives but his acquaintance with foreign archives seems practically limited to such fragments from them as Schanz saw fit to print thirty years ago. Schulz has demonstrated how essential a study of the German archives, particularly those of Cologne, is to a proper understanding of English trade relations with Germany, and there can be little doubt that the Dutch and French archives would have amply repaid investigation. Mr. Williamson, either from lack of opportunity or from that obstinate insularity which still, unfortunately, characterizes too many English historians, has been content to accept the English view of the matter. His conclusions are therefore not likely to carry great weight with serious students.

The letter-press of the book is excellent and the illustrations positive contributions to the subject. Several contemporary maps and contemporary pictures of sixteenth-century ships have been admirably reproduced.

University of Chicago

Conyers Read

A Model Housing Law. By Lawrence Veiller. New York: Survey Associates, Inc., I9I4. 8vo, pp. viii+343. \$2.00.

This book is an extension of $A$ Model Tenement House Law. It contains an interesting, though not universally accepted, outline of how to secure housing reform; a comparison of codes, tenement-house laws, and housing laws; directions as to how to use the text; and a sample law, with useful notes on the various sections.

Mr. Veiller has rendered a distinct service in preparing a sample law which is properly classified and co-ordinated. The articles-General Provisions, Dwellings Hereafter Erected (light and ventilation, sanitation, fire protection), Alterations, Maintenance, Improvements, Requirements, and Remedies-are in arrangement a distinct advance over the hodgepodge usually found. Anyone preparing a law cannot do better than to follow this arrangement. There are minor defects and it should not be followed without careful study, but its use will enormously simplify the work of preparing a local law. Laws of this kind are essentially a new venture in this country and yet this book carries the beginner far on the road toward a satisfactory conclusion.

It is with Mr. Veiller's thesis in his first chapter, "Housing Reform through Legislation," that many will have to take exception. But 
even here his work is more useful than he is willing to admit. He says: "To the social reformer who believes that the solution of the housing problem is to be found in a change in methods of taxation or in a new industrial era this book will have but little interest." There is a large and rapidly growing school of thinkers who believe housing reform to be fundamental, but who think the housing problem is both a result and a cause of other problems, and who therefore want to solve the problems producing the housing problem, and to solve the housing problem to get at its results.

All such people desire housing legislation and they will find $\mathrm{Mr}$. Veiller's book helpful, very helpful. But they see the need for other things than he suggests. To stop with housing legislation alone will result in materially increasing the cost of homes, although naturally improving their quality. And legislation alone does not guarantee a sufficient number of homes. There are certain economic laws, as pointed out by Mr. John Nettlefold in Practical Town Planning, which must be recognized. Mr. Nettlefold says that certain legislative acts can easily contravene economic laws and thereby hinder progress instead of helping it. All housing reformers must use Mr. Veiller's book, but they must also consider the co-ordinate problems of taxation, assessing, planning, transportation, improvements, immigration, wages, labor, industry, privilege.

Mr. Veiller's sample law will therefore be universally useful, but his general statements will have to be considered as from one somewhat too deeply immersed in his own specialty.

Boston, Mass.

EDWARd T. HARTMAN

\section{A History of Emigration from the United Kingdom to North America,} I763-rgr2. By Stanley C. Johnson. New York: E. P. Dutton \& Co., I9I4. 8vo, pp. xvi+387. \$2.00 net.

From the viewpoint of the patriotic American, the present immigrant is a problem. The demand for the immigrant to aid in the development of our resources is not so insistent as it was formerly. The pronounced change in the character of immigration since 1885 has aroused solicitude for the maintenance of our standards of living and economic prosperity. The Slav and the South Italian are not welcomed as cordially as the Teuton and the Briton were. It is complained that the new immigrants bring too small a contribution to our national wealth; that they send too 